\title{
Information Technology (IT) Competencies Desired in New Accounting Graduates: A Survey in Jordanian Business Environment
}

\author{
Suleiman Mustafa El-Dalahmeh ${ }^{1}$ \\ ${ }^{1}$ Accounting Department, Faculty of Economic and Administrative Sciences, Jerash University, Jordan \\ Correspondence: Suleiman Mustafa El-Dalahmeh, Accounting Department, Faculty of Economic and \\ Administrative Sciences, Jerash University, Jordan. E-mail: dr.el-dalahmeh97@live.com
}

Received: January 1, 2017

Accepted: March 12, 2017 Online Published: April 27, 2017

doi:10.5539/ijbm.v12n5p202

URL: https://doi.org/10.5539/ijbm.v12n5p202

\begin{abstract}
Accounting and information technology are closely related for many decades. Accounting was the domain of business that first adopted IT and made an extensive use of it. Nowadays the IT competencies desired by accountants were under a continuous change and evolution. Modern accountants are expected to have a high level of IT knowledge and skills and towards that direction the curriculum in accounting education have to adopt a wide range of modules in order to provide accounting students with the required competencies. The paper presents the results of a survey in Jordanian business environment regarding technological skills desired in new accounting graduates. The questions related to computer skills desired in new accounting graduates showed that spreadsheet knowledge was the most desired followed by accounting software, for casting packages as well as all the skills mentioned in the questionnaire ranged between the importance degree is very high and high.
\end{abstract}

Keywords: accounting, information technology, IT competencies, IT knowledge and skills, new graduate

\section{Introduction}

At the present time, with the increasing important of information technology and globalization of the world economy, the role of accountants is not as simple, they are not only to prepare the financial statement, auditing, and financial reporting, accountants also playing the role as information facilitators (Yasin, Boyes, \& Czuchry, 2005) new accounting graduates thus need to learn more technological skills, management skills, and information system and more (Elliottod Jacobson, 2002).

The dissatisfaction with the skills and knowledge demonstrated by accounting graduates entering the labor market has been of concern to employers for a number of years (Cory \& Pruske, 2012).

The question that arises is how academics can help accounting learners meet the set of skills demands at recruitment and in their advanced accounting careers (De villiers, 2010) (Kavanagh \& Drennan, 2008) an understanding of the broad and complex set of skills demands of employers is essential.

In general, accounting department of most universities strives for continuous development in their accounting curriculum to provide a quality education, that will satisfy the needs of various stakeholders mainly employers, and enable new accounting graduates to succeed.

The examination of technological competencies and skills desired in new accounting graduates that employers need in order to enter them in the curriculum is essential to adders where the curriculum might fall short (Hodgas \& Burchell, 2003).

What is not clear is the set of skills generally agreed upon by key stakeholders in accounting education has focused on the views of academia, and employers in the developing world (Awayiga, Onumah, \& Tsameny, 2010), (Abayadeera \& Watty, 2014).

However, in Jordan accounting education is challenged by the major change in the business environment, in which professional accountants are operating. The main factor that affects Jordanian business environment is the impact of information technology on the accountant profession because technical skills are essential for the new accounting graduates to enter the job market; they need to improve their competencies in this fast changing environment.

Jordanian universities commonly obtain feedback from current students, graduates, or employer on the extent to 
which a program prepares new graduates for labor job. In fact, the skills development gap existed between the expectation of employers and new accounting graduate.

\subsection{Purpose of the Study}

This paper sought to identify the kinds of information technology competencies desired in new accounting graduates perspective of accountants in Jordanian business environment.

\section{Literature Review}

Much has been written about the technological competencies desired in new accounting graduates. The AICPA's (1999) Technology Curriculum and Competency Model Task Force (1999) have published its findings that technological changes are among the most important challenges facing the accounting profession. They listed three challenges facing accounting education as being:

1- Information technologies are affecting the way in which organizations operate. 2- Information technologies are changing the nature and economic of accounting activity. 3- Information technologies are changing the competitive environment in which accountants participate. The AICPA committee concluded that as a result of these changes, academic preparation today must include increasing amounts of information technology training. They also concluded that all professional accountants must acquire an essential body of IT knowledge.

The AICPA committee published five categories of General information technology information requirements. These are: Information Technology Concepts for Business system, Internal Control in Computer Based Business system, Development Standards and Practices for Business system, Management of IT Adoption, Implementation, and Use and Evaluation of Computer Base Business System.

The AICPA's Core Competency Framework for Entry into the Accounting Profession also stresses the need for accountants to be familiar with technology. Under the category of Functional Competencies, the framework mentions the need for accountants to be able to access an electronic database, assess the risk of technology and automated business process, use technology to assess and control risk and document work performed and build appropriates models and simulations using electronic spreadsheets.

Davis (1999) found that computer literacy requirements for all job levels increased dramatically over a three - year period in the early nineties. However, they also found that recent college graduates lack computer literacy skills. This situation is also true in the accounting profession.

The Journal of Accountancy (2000) reports the results of a survey of 400 companies describing the personal and business skills accountants and finance professionals can acquire to increase their chances for being promoted. The survey found that information technology was mentioned by the most companies (about 62\%) as the professional skills CPA's should concentrate on developing in order to get ahead in their careers.

Albrecht \& Sack (2000) state one of the reasons why practicing accountants and educators would not study accounting today is because technology has made much of what accountants do obsolete and the demand for the traditional work of accountants, audit, and tax, has decreased. Elliott (2000) describes the CPA of the future as a "person skilled in information leveraging, someone who helps individuals and organization achieve their objectives through are strategic use of information and information system" This emphasizes the fact that accountants will have to be familiar with Information Technology (IT).

Prior research on graduates skills and capabilities has tended to focus identifying the perceived generic skills and capabilities in practice as perceived by:

1- Recruiter and employers (Gammie, \& Cargill,2002; Hassall, Joyce, Montano, and Anes J.A.D,2003; Morgan,1997; Schmutte, 1998; Wronck, 1997).

2- graduates (De Lange, Jackling \& Gut A.M.,2006) studies found that high school teachers and counselor didn't consider generic skills and capabilities important for accounting practices (Berry et al., 2001; Hardin et al., 2000; ) (Wells \& Fieger, 2006). However, undergraduates students perceptions of the required generic skills and capabilities of accountants developed as the progressed through their studies (Read \& Kratchman, 1989; Warnock, 1997).

Despite the development of this perception, it was found that a gap still existed between students and employers regarding the perceived skills requirement of accountants (Hassall et al., 2003).

Richard B. Dull et al. (2005) they conducted a study to evaluating the importance of competencies within accounting information systems (AIS) Curricula. The study showed that information about relative importance to accounting professional would be a useful reconciliation of the difference in academic and professional assessment 
would be an ultimate goal, helping each understand and recognize the attitudes and expectation of the other.

Klibi and Pussii (2013) the researchers conducted an empirical study entitled "skills and attributes needed for success in accounting career" do evidence from Tunisia. This study aimed to examine perception and expectations of two major stakeholders: students and employers of the importance of skills and attributes for securing entry-level employment in accounting. The study indicates that employers are seeking graduates who possess a diverse range of on- technical skills. However, accounting students perceive that it is rather technical skills which determine their abilities to pursue a career in the accounting professional.

Seedwell Tanka Mayko Sithole (2015) conducted a survey in Australia on accounting knowledge and skills desired by the employer and their level of satisfaction with skills demonstrated by entry level accounting graduates.

The survey found that the computing techniques, written communication, and reporting skills are required by employers. In contrast, employers perceive accounting graduates to be highly skilled in measurement skills, reporting skills, and research skills. Furthermore, as far as technological skills are concerned, employers indicated that the students are better trained in world processing and knowledge of communication, software skills, yet employers expect more knowledge of accounting packages and spreadsheet competencies for entry-level graduates.

Mary Low et al. (2016). They conducted a study to examined what accounting employers are seeking in their ideal accounting graduates and sought to provide clarification on expectation gap between what accounting employers required in their graduates, and the skills these graduates are exhibiting. Adopting a qualitative research method. The study revealed that in terms of technical skills, employers require at least a sound understanding of the fundamental technical accounting skills. However, beyond this little more is expected technically of graduates as the requisite technical skills are learned on the job. Finding also suggests that the touted expectation gap is not as prior literature has suggested. Over half of the employers also believed universities are preparing students adequately for the workplace, although this seems to be moderated by an opinion among employers that this is as well as an academic institution can do.

\section{Methodology}

The study reports the results of a survey of accountants in Jordanian business environment regarding the desired technological competencies for new accounting graduates. The questionnaire was distributed personally to a random sample of 250 accountants. (154) questionnaires were returned, and the response rate of which was $61.6 \%$. These accountants working in the Jordanian banks, investment, insurance, finance managers, finance controllers, industrial, auditors, business services. It is to be noted that a majority of the respondents possessed professional qualifications such as JCPA, CPA, and CMA only a minority graduates or postgraduates in accounting, even finance managers and finance controllers had an accounting background and some of them had MBAs in finance.

The average experiences of respondent were about 10 years with a maximum more than 15 years and minimum of 5 years at the time of conducting this survey. The purpose of the above analysis was to ensure that accounting professionals who have experience and interest in desired information technology competencies for new accounting graduates and development in Jordanian business environment who completed the survey.

\subsection{Study Tool}

After reviewing the previous studies and the literature of accounting education regarding technological competencies for new accounting graduates to enter the labor market. The research developed a questionnaire which included (23) items relating to computer applications used by accountants in Jordanian business environment. The survey also asked whether the company offered computer training newly hired accountants and in what areas.

\subsection{Statistical Test}

Statistical methods applied to analyze data are means, standard deviations, and percentages.

\subsection{Scale}

Likert scale was adopted, which consists of five degrees to determine how much the responders agree or disagree with each item in the questionnaire as how in Table 1. 
Table 1. Likert scale

\begin{tabular}{ll}
\hline Scale & Degree \\
\hline Strongly disagree & 1 \\
Disagree & 2 \\
Neutral & 3 \\
Agree & 4 \\
Strongly agree & 5 \\
\hline
\end{tabular}

To interpret Likert scale results, weighted mean to represent each question was computed. Table (2) shows the level of agreement associated with each weighted average mean range.

Table 2. Weighted mean level of agreement

\begin{tabular}{ll}
\hline Weighted mean & Level of agreement \\
\hline More than $4.2-5$ & Very high \\
More than $3.4-4.2$ & High \\
More than $2.6-3.4$ & Average \\
More than $1.8-2.6$ & Average \\
1.8 and less & Very week \\
\hline
\end{tabular}

\section{Results}

Table 3 shows the results of respondents regarding the size, in terms of people of the companies surveyed. Respondents to the survey came from Jordanian business environment neither large nor small companies. As can be seen from the table $56 \%$ of the respondents came from companies with than more 101 employees. $30 \%$ of the respondents came from 20 to 100 employees and 14\% of the response came from 5 to 19 employees. In my opinion, there is a good cross - section of small and big companies in the sample which providing a basis for finding out the desired (IT) competencies for new accounting graduates.

Table 2. Companies' size in terms of people

\begin{tabular}{lll}
\hline Size & Frequency & Percentage \\
\hline $5-19$ & 7 & $14 \%$ \\
$20-100$ & 15 & $30 \%$ \\
More than 100 & 28 & $56 \%$ \\
Total & 50 & $100 \%$ \\
\hline
\end{tabular}

Table 3. Information technological competencies desired in new accounting graduates

\begin{tabular}{|c|c|c|c|c|c|c|c|}
\hline No & Items & Mean & St.dv & Percentages & Importance & SIG & T-test \\
\hline 1 & Financial spreadsheet & 4.50 & 0.68 & $90 \%$ & Very high & $0.00 * *$ & 13.90 \\
\hline 2 & Flowcharting and database & 4.33 & 0.66 & $86.6 \%$ & Very high & $0.00 * *$ & 11.74 \\
\hline 4 & $\begin{array}{l}\text { Financial instruments } \\
\text { software }\end{array}$ & 4.33 & 0.87 & $86.50 \%$ & Very high & $0.00 * *$ & 9.43 \\
\hline 5 & $\begin{array}{l}\text { General ledger Package } \\
\text { Software }\end{array}$ & 4.35 & 0.66 & $87 \%$ & Very high & $0.00 * *$ & 12.89 \\
\hline 6 & Accounting Software & 4.48 & 1.01 & $89.6 \%$ & Very high & $0.00 * *$ & 15.6 \\
\hline 7 & Audit software & 4.20 & 0.96 & $84 \%$ & Very high & $0.00 * *$ & 7.80 \\
\hline 8 & ERP system software & 4.13 & 0.99 & $82.50 \%$ & High & $0.00 * *$ & 7.17 \\
\hline 9 & Presentation & 4.40 & 0.67 & $88 \%$ & Very high & $0.00 * *$ & 13.19 \\
\hline 10 & Industry Specific Software & 4.33 & 0.66 & $86.50 \%$ & Very high & $0.00 * *$ & 12.79 \\
\hline 12 & Tax preparation software & 4.23 & 065 & $85.59 \%$ & Very high & $0.00 * *$ & 12.39 \\
\hline
\end{tabular}




\begin{tabular}{|c|c|c|c|c|c|c|c|}
\hline 13 & Decision support software & 4.35 & 0.66 & $87.00 \%$ & Very high & $0.00 * *$ & 12.89 \\
\hline 14 & $\begin{array}{l}\text { Statistical analysis } \\
\text { packages }\end{array}$ & 4.43 & 0.71 & $88.50 \%$ & Very high & $0.00 * *$ & 13.16 \\
\hline 15 & Forecasting packages & 4.47 & 0.60 & $89.40 \%$ & Very high & $0.00 * *$ & 12.90 \\
\hline 16 & Utility Programs & 4.03 & 0.92 & $80.50 \%$ & High & $0.00 * *$ & 7.05 \\
\hline 17 & $\begin{array}{l}\text { Operating and managing } \\
\text { System }\end{array}$ & 3.83 & 0.84 & $76.6 \%$ & High & $0.00 * *$ & 6.18 \\
\hline 18 & $\begin{array}{l}\text { Safeguarding of system } \\
\text { against unauthorized use }\end{array}$ & 3.65 & 1.10 & $73 \%$ & High & $0.00 * *$ & 3.74 \\
\hline 19 & $\begin{array}{l}\text { Software piracy, virus } \\
\text { attacks and system failure }\end{array}$ & 4.36 & 0.56 & $87.27 \%$ & Very high & $0.00 * *$ & 13.11 \\
\hline 20 & $\begin{array}{l}\text { Communications software } \\
\text { (e-mail) the Internet }\end{array}$ & 4.35 & 0.62 & $87 \%$ & Very high & $0.00 * *$ & 9.82 \\
\hline 21 & IT assurance need & 3.80 & 1.24 & $76 \%$ & High & $0.00 * *$ & 4.06 \\
\hline 22 & Small business system & 4.38 & 0.63 & $87.5 \%$ & Very high & $0.00 * *$ & 13.15 \\
\hline \multirow[t]{2}{*}{23} & Video Conferences & 4.28 & 0.78 & $85 \%$ & Very high & $0.00 * *$ & 13.96 \\
\hline & Total degree & 4.25 & 0.85 & $85 \%$ & Very high & $0.00 * *$ & 12.35 \\
\hline
\end{tabular}

* Denotes the p-value signification at $0.05 * *$ signification at $10 \%$.

Table 4 shows that the means of information technological (IT) competencies desired in new accounting graduates ranged between 4.50 and 3.65, the highest three means were for technological competencies desired in new accounting graduates number (1), (6) and (15) and the lowest three means were for technological competencies desired number in new accounting graduates number (17), (21) and (18). Table 4 also shows that the degree of importance, ranging from very high and high it got (17) items ( very high ) and (6) items (high). Total degree: mean was (4.25), the standard deviation was (0.85), percentage (85) and importance degree very high. These results indicate that there is no much variation in the study sample responses.

The result of T-test for one set showed that the overall mean degree of approval for technological competencies desired in a new accounting graduates is more than a statistically significant value 3 , where the value of the T-test for the difference between the overall mean and value $3=(12.35)$ a positive, $\alpha$ the Value of the type 1 error $\alpha=0.00<0.05$. Based on that the level of technological competencies desired in new accounting graduates (very high), percentage $85 \%$.

Table 5 shows the responses regarding the desirability of students with minors in information technology. (85.7\%) of accountants. In Jordanian business environment desired students to possess not an only degree in accounting but also a minor information technology. From this result, I can say that the Jordanian labor market prefers those within computer skills next to their specialization in accountancy.

Table 4. Increased desirability of students with minors in information technology

\begin{tabular}{lll}
\hline & Frequency & Percentage \\
\hline yes & 132 & $85.7 \%$ \\
No & 8 & $5.2 \%$ \\
Maybe & 10 & $6.5 \%$ \\
Did not answer & 4 & $2.5 \%$ \\
Total & $\mathbf{1 5 4}$ & $\mathbf{1 0 0 \%}$ \\
\hline
\end{tabular}

Table 6 also shows the answers that respondents gave when asked if there was on the job training for computer training programs used by the company, the table indicates that the $87 \%$ of companies offer such training courses. The researcher believes that such a large percentage of companies offering training indicate the value that companies place on having computer literature employees. Table 6 reveals that $6.5 \%$ of companies do not offer training courses. The researcher attributes these to the small size of these companies; do not have provisions for training and using simple computer applications. 
Table 5. Training programs in computer applications

\begin{tabular}{lll}
\hline Training & Frequency & Percentage \\
\hline Yes & 134 & $87 \%$ \\
No & 10 & $6.5 \%$ \\
Don't know & 6 & $3.9 \%$ \\
Did not answer & 4 & $2.6 \%$ \\
Total & $\mathbf{1 5 4}$ & $\mathbf{1 0 0 \%}$ \\
\hline
\end{tabular}

\section{Conclusion}

The survey results show that the Jordanian business environment desires new accounting graduates who have information technology knowledge. The results reveal that both small and large companies seek new accounting graduates who possess a very good understanding of computer application programs. The result also shows the $87 \%$ of Jordanian companies provide training in computer applications.

Based on the statistical analysis, the researcher was able to conclude that Jordanian companies rely in its work on computer application programs, therefore; accounting graduates must possess desired computer skills and technological competencies that enable them to enter the labor market.

A large proportion of respondents indicated the accountants in their companies were using the financial spreadsheet application. This would indicate that accounting graduates who don't possess spreadsheet knowledge would be at a disadvantage. Other technological skills such as General ledger packages software, word processing. Flow charting and database, financial instrument software, accounting software, audit software, ERP system software, presentation, Tax preparation software, statistical analysis packages and applications were also desired. These results show that accounting and information technology are closely related, and modern accountants are expected to have a high level of IT knowledge and towards that direction the curriculum in accounting education have to adopt a wide range of modules in order to provide accounting students with the required competencies. The results of the survey confirm the results of previous surveys such as those conducted. By (Davis, 1999, Albrecht \& Sack, 2000) which indicate that spreadsheet applications are the most important skills utilized by accountants. $85.7 \%$ of respondents also indicated the desire for accounting students to possess a minor in computer information technology. This would indicate that information technology considered imperative for accountants in order to perform their tasks.

\section{References}

AICPA Integration of Technology into the Learning Experience Task Force. (1999). Retrieved from http://www.aicpa.org/edu/taskfro.htm

Albrecht, S. W., \& Robert, J. S. (nd.). Accounting Education: Charting the course through a perilous future. American Accounting Association. from https://www.imanet.org/-/media/eb5185f1048846d1bbbc37e004f4ceec.ashx

Davis, P. (1999). What computer Skills do Employees Expect from Recent College Graduates? Cornell University, Ithaca.

Elliott, Robert K, who are we as a profession - and what must we become? Journal of Accountancy. Retrieved from http://raw.rutgers.edu/docs/Elliott/05Who\%20we\%20are.pdf

Yasin, M. M., Bayes, P. E., Czuchry, A. J. (nd.). The changing role of accounting in supporting the quality and customer goals of organizations: An Open system perspective. International Journal of management, 22(3), 323-332.

Elliot, R. K., \& Jacobson, P. D. (nd.). The Evolution of knowledge professional. Accounting Horizons, 16(1). Retrieved

from http://raw.rutgers.edu/docs/Elliott/02The\%20Evolution\%20of\%20the\%20Knowledge\%20Proff.pdf

Deppe, L. A., \& Sonderegger, E. O. (1991). Emerging competencies for the practice of Accounting. Journal of Accounting Education, 9(2), 257-290.

Richard, B., Dull, S. A. Webber, B. A., \& John, M. H. (2005). Evaluating the importance of competencies within Accounting Information System Curricula. The review of Business Information System, 9(2).

Abayadeera, N., \& Watty, K. (2014). The expectation-performance gap in generic skills in accounting. 
Awayiga, J. Y., Onumah, J. M., \& Tsamenyi, M. (2010) Knowledge and skills development of accounting graduates: The perceptions graduates and employers in Ghana. Accounting Education: An international Journal 19(1-2), 139-158.

De Villiers, R. (2010). The incorporation of soft skills into accounting curricula: preparing accounting graduates for the unpredictable future. Meditari. Accounting Research, 18(2), 1-22.

Cory, S. N., \& Pruske, K. A. (2012). A factor analysis of the skills necessary in accounting graduates. Journal of Business and Accounting, 5(1), 121-128.

Hodges, D., \& Burchell, N. (2003). Business graduate competencies: Employers, views on importance and performance. Asia-pacific Journal of Cooperative Education, 4(2), 16-22.

Kavanagh, M.H., \& Dernnan, L. (2008). What Skills and attributes does an accounting graduate need? Evidence from student perception and employer expectations. Accounting \& Finance, 48(2), 279-300.

Berry, K. T., O'Bryan, D., \& Swanson, P. K. (2001). High School Business Education perceptions of the knowledge, skills, and abilities needed by accounting majors relative to other business majors. Paper presented at the AAA north east regional meeting portland, Maine. Retrieved from http://jite.org/documents/Vol3/v3p133-142-114.pdf

De Lange, P., Jackling, B., \& Gut, A. M. (2006). Accounting graduates perceptions of skills emphasis in undergraduate courses: An investigation from two Victorian universities. Accounting and Finance, 46(3), 365-386.

Gammie, B., Gammie, E., \& Cargill, E. (2002). personal skills development in the accounting curriculum accounting education. An International Journal, 11(1), 63-78.

Hardin, J. R., O’Bryan, D., \& Quirin, J. J., Reckers, P. M. J. (2000). Accounting versus engineering. Lawrd Medicine: perceptions of influential High school teachers. Advances in Accounting, 205-220. Press Inc Stamford. CA.

Hassall, T., Joyce, J., Montano, J. L. A., \& Anes. J. A. D. (2003). The vocational skills gap for management accountants: The staleholders perspectives. Innovations in Education and Teaching International, 40, 78-88.

Morgan, G. (1997) communication skills required by accounting graduates: Practitioner and academic perceptions. Accounting education: An international Journal, 6(2), 83-107.

Reed, S. A., \& Kratchman, S. H. (1989). A longitudinal and cross-sectional stuffy of students perceptions of the importance of Job attributes. Journal of Accounting Education, 7(2), 171-193.

Schmutle, J. (1998). Student characteristics: A longitudinal study. Journal of Accounting Education, 16(3), 429-461 cross ref

Warnock, K. K. (1997). Selecting the accountants of the future. Accounting Ireland, 29(3), 6-7.

\section{Copyrights}

Copyright for this article is retained by the author(s), with first publication rights granted to the journal.

This is an open-access article distributed under the terms and conditions of the Creative Commons Attribution license (http://creativecommons.org/licenses/by/4.0/). 